\title{
Knowledge, Attitude and Practice of COVID 19 and the factors influencing them among a Rural Population in South India
}

\author{
Jenit Osborn ${ }^{1}$, Kamakshi Priya $\mathrm{K}^{2}$, Satheesh $\mathrm{T}^{3}$, Sudha Ramalingam ${ }^{4}$
}

${ }^{1}$ Assistant Professor, Department of Community Medicine, PSG Institute of Medical Sciences \& Research, Coimbatore, India; ${ }^{2}$ Post Graduate Student, Department of Community Medicine, PSG Institute of Medical Sciences \& Research, Coimbatore, India; ${ }^{3}$ Senior Resident, Department of Community Medicine, PSG Institute of Medical Sciences \& Research, Coimbatore, India; ${ }^{4}$ Professor, Department of Community Medicine, PSG Institute of Medical Sciences \& Research, Coimbatore, India

\begin{tabular}{|l|l|l|l|l|l|l|l|}
\hline Abstract & Introduction & Methodology & Results & Conclusion & References & Citation & Tables / Figures \\
\hline
\end{tabular}

\section{Corresponding Author}

Dr. Sudha Ramalingam, Director, Research and Innovation, Professor, Department of Community Medicine, Co-Director PSG FAIMER Regional Institute PSG Institute of Medical Science and Research, Coimbatore, India.

E Mail ID: drsudhapsg@gmail.com

\section{Citation}

Osborn J, Priya KK, Satheesh T, Ramalingam S. Knowledge, Attitude and Practice of COVID 19 and the factors influencing them among a Rural Population in South India. Indian J Comm Health. 2021;33(1):193-197. https://doi.org/10.47203/IJCH.2021.v33i01.027

Source of Funding: Nil Conflict of Interest: None declared

\section{Article Cycle}

Received: 13/11/2020; Revision: 09/01/2021; Accepted: 28/01/2021; Published: 31/03/2021

This work is licensed under a Creative Commons Attribution 4.0 International License.

\section{Abstract}

Background: Mitigation measures to control the novel coronavirus disease 2019 (COVID-19) depends on the public adherence to preventive measures which is influenced by their knowledge and attitude. Aim: To find the knowledge, attitudes and practices (KAP) of the rural population toward COVID-19 and to establish its sociodemographic influencing factors. Material and methods: KAP study regarding Covid-19 was done among the rural population during August 2020 using a semi-structured questionnaire. Results: Among 500 participants, the mean knowledge, attitude and practice score was 21.55 2.9 (Range 0- 30 ), 30.0 2.88 (Range 12- 36 ) 9.4 1.25 (Range 0-13 ) respectively. Higher knowledge was associated with higher education and employed individuals. Favourable attitude was among those aged $<35$ years and having higher education. Optimistic practices were exhibited by employed individuals and when children $<12$ years are present in their home. Conclusions: Study participants preceded good knowledge, positive attitude towards COVID-19 but practice is not sufficient enough to win the battle against the dreadful disease due to considerable knowledge- practice gap.

\section{Keywords}

COVID-19; Knowledge; Attitude; Practice; Rural Population

\section{Introduction}

COVID-19 virus which emerged in Wuhan has spread over 200 countries and has become a pandemic claiming several lives. World Health Organization (WHO) announced a public health emergency of international concern to prevent its rapid spread.(1)In India, a confirmed case of COVID-19 was reported on 30thJanuary 2020, who was a student travelled from Wuhan, China.(2) More than eight million cases have been reported so far in India.[3] Tamilnadu, a state in India has the third largest number of cases approximately 7,30,000 cases till date.(3) While the government has issued advisory through various channels and media on the prevention and precautionary measures, people's observance is essential for controlling the spread of 
COVID-19, which is affected by their knowledge, attitudes and practices (KAP) towards COVID-19. From compliance with lockdowns to following personal safety measures, the onus is on each individual to break the chain and flatten the curve.(4) While the urban community has the advantage and access of health care facilities and other ways of becoming aware of these measures such as social media and print media, the rural population may be limited in terms of access and awareness of these updates.(5) In addition, the recent trends indicate that the COVID crisis is moving towards the rural areas.(5) Considering the above facts it is more important and imminent to reach out to the community in a rural area to assess their knowledge, attitude and practice towards COVID 19 and recommend tailor made awareness programs to these population so that the disease control measures are effective and on-going prevention efforts can be strengthened. Therefore, we conducted a survey to investigate the knowledge, attitude and practice (KAP study) towards COVID-19 among the rural population as well as to find the socio-demographic determinants associated with it.

\section{Aims \& Objectives}

1. To study the knowledge, attitude and practice (KAP) among the rural population towards COVID-19

2. To find the socio-demographic determinants influencing KAP among the study participants

\section{Material \& Methods}

Study population and location: This cross-sectional study was conducted among those who attended the outpatient clinic at the PSG Rural Heath Training Centre (RHTC) attached to Department of Community Medicine in Coimbatore.

Questionnaire: A self-designed questionnaire was developed from WHO training material for emerging respiratory viruses including COVID-19(6) and Training Resources for COVID 19 Management in India. (7) Demographic details had questions on age, gender, occupation, education, socioeconomic class and presence of children less than 12 years. Knowledge section had 30 questions which dealt with clinical symptoms, transmission, high risk groups, prevention and control of COVID-19. Participants were asked to respond to knowledge items as either true or false, with an additional "don't know" option. The correct answer was assigned a score of one and false/l don't know answers were given a score of zero. The total score for knowledge ranged from zero to 30 with high score representing better knowledge. Those who scored more than $70 \%$ of the score were considered as having adequate knowledge based on previous study.(8)

In the section on attitude, scores were calculated based on the respondents' answers to each of 12 attitudinal statements in likert scale as agree, neutral and disagree. Agree or Disagree was awarded 3 points based on positive or negative statement and the reverse one was given one point, neutral answer was given a score of 2 . The total attitude score ranged from 12 to 36 with high scores indicating positive attitudes. In the section on practices, respondents were asked to respond "yes" or "no" to the 13 items. A score of one was given to answers that reflected good practice and a score of zero was given for wrong practice. Total practice score ranged from 0 to 13 higher averages represents a desirable practice.

Data Collection: IHEC clearance was obtained for the study. Convenient sampling method was used to enroll the participants attending the RHTC owing to the current pandemic situation and to conduct the physical interview with safety precautionary measures until a sample size of 500 was reached during the period of August 10 to August 30. Data was collected among permanent residents in the catchment area above 18 years after obtaining a detailed written informed consent.

Statistical analysis: Data was collected using epicollect app and was analyzed using SPSS (v20) software. Normality of the score was assessed using a test of normality - Kolmogorov-Smirnov and Shapiro-Wilk test. Comparison of KAP scores with demographic factors was done using independent samples t-test. Multivariate linear regression analysis was used to establish the relationship between independent variables and KAP outcome variable. $P$ value $<0.05$ was considered as statistically significant.

\section{Results}

Demographic information: Demographic profile of the enrolled 500 participants is shown in table 1 . The mean age of the study participants was $37.49 \pm$ 13.16. Among the participants who responded $52.6 \%$ were in the age group $\leq 35$ years, $60.8 \%$ were females, $59 \%$ were employed with salary, $62.8 \%$ were educated above high school, $18.4 \%$ belonged 
to socio-economic class IV \& V and $39.4 \%$ had children less than 12 years in their home.

Knowledge, Attitude and Practice Score related to COVID-19: The mean knowledge score was 21.55 2.9 (Range $0-30$ ). $65.8 \%$ of the participants scored more than $70 \%$ and were considered as having adequate knowledge. $89 \%$ of them knew wearing mask help to reduce the transmission of the disease. $87 \%$ of the individuals said washing hands with water and soap can eliminate the disease causes. Nearly everyone (97.2\%) knew that COVID-19 can be prevented by avoiding crowded places. The mean attitude score was $30.0 \pm 2.88$ (Range 12- 36). Majority of population (96.4\%) believed restriction of travel to contaminated area along with social distancing, wearing mask regularly and practising hand hygiene helps to prevent disease spread. 94.8\% felt mental health of COVID-19 infected patients should be taken care. The mean practice score was $8.2 \pm 1.25$ (Range $0-13$ ). Majority (99.6\%) of the participants use facial mask whenever they go out of home but $39.2 \%$ have the habit of keeping the mask in the pocket and use it when required, 50.4\% have the habit of pulling down the mask when talking to their friends / relatives $.82 \%$ avoid going out of home unnecessarily. Higher proportion (96.8\%) of the participants practice washing hands with soap/ use sanitizer but only $36.6 \%$ wash hands with soap for at least 20 seconds.

Predictors for KAP regarding COVID_19: In multivariate regression analysis (as shown in Table 2) employed individuals $(\beta=0.73$ : $p=0.016)$, Higher education ( $\beta=1.35: \quad p=0.002)$ have significant association with higher knowledge score. With regard to attitude those aged $\leq 35$ years $(\beta=0.69$ : $p=0.016)$, Higher education $(\beta=0.75: p=0.012)$ have good attitude score and is found to be statistically significant. Employed individuals ( $\beta=0.53$ : $p=0.002$ ) those who have children less than 12 years in their home $(\beta=-0.31: p=0.010)$ have significant good practice.

\section{Discussion}

The battle against the novel COVID-19 is still in progress in India and evidence shows that public knowledge is important in tackling pandemics. Adequate knowledge was present among $65.8 \%$ of the study participants. The knowledge acquired can be due to familiarity of the disease since this pandemic is in existence for more than six months. Significant predictors of participant knowledge were those who have education more than 10th standard and employed with salary. This supports the claim that educated and employed individuals have exposure to different information-gathering networks hence they are much aware which is consistent with other study. (9)

A positive and optimistic attitude among the study participants reflects the belief that COVID-19 was controllable and containable. Attitude was strongly associated with participants aged $\leq 35$ years and those having higher education consistent with another study. (10) The younger generation use social media more often than the elderly individuals in the rural area which could have influenced their attitude.

Good practice indicates the translation of knowledge and attitudes into practices (behavioural change) which is a crucial determinant to control the disease. Despite government mitigation measures like restriction on public transport, gatherings, closures of theatres and malls etc. to enforce social distancing still practice measures are not satisfactory. Though $89 \%$ of them are aware that wearing mask can reduce the transmission unfortunately nearly onethird of the participants has the habit of keeping the mask in their pocket and uses it when necessary and $50 \%$ have the habit of pulling down the mask while talking to their friends/relatives which hinder the purpose of using face mask. Similarly, though $87 \%$ of the individuals knew washing hands with water and soap can eliminate the disease only $36.6 \%$ wash hands with soap for at least 20 seconds. The predictors for optimistic practices in our study are employed individuals and presence of children less than 12 years in their home which was similar to another study. (9)

The current study has few limitations since community based sample surveys could reflect better KAP assessment but in the current situation it is not advisable. This study is one of the first among rural population assessing peoples' knowledge, attitudes, and practices toward COVID-19 and thus provides a useful baseline for future research. Though knowledge score is better in this study, good practice is inadequate which poses a major threat in the spread of the disease. There is a huge gap between knowledge and practice which emphasize an immediate need to address this gap for better disease control measures. Owing to relaxation of lockdown - colleges, schools, theatres and malls have started to function, so the potential barriers has to 
be curbed and harness better practice in order to prevent the second wave of transmission.

\section{Conclusion}

There is a huge gap between knowledge and practice which emphasize an immediate need to address this gap for better disease control measures. Owing to relaxation of lockdown - colleges, schools, theatres and malls have started to function, so the potential barriers has to be curbed and harness better practice in order to prevent the second wave of transmission.

\section{Recommendation}

This study is one of the first among rural population assessing peoples' knowledge, attitudes, and practices toward COVID-19 and thus provides a useful baseline for future research. Encouragement of public to adopt precautionary behaviours for containment strategies as knowledge attitude and practice is foreground for public cooperation and backbone for implementing any health policy. Good practice indicates the translation of knowledge and attitudes into practices (behavioural change) which is a crucial determinant to control the disease.

\section{Limitation of the study}

Community based sample surveys could reflect better KAP assessment among rural population but in the current situation it is not advisable.

\section{Relevance of the study}

COVID-19 is an emerging infectious disease that poses a significant threat to public health. Preventive measures play an essential role in reducing infection rates and controlling the spread of the disease. This indicates the necessity of public adherence to preventive and control measures, which is affected by their knowledge, attitudes, and practices (KAP). Though knowledge score is better in this study, good practice is inadequate which poses a major threat in the spread of the disease.

\section{Authors Contribution}

All the authors have contributed at various stages of composition of the final manuscript.

\section{Acknowledgement}

We would like to express our gratitude to all the participants enrolled in the study for their cooperation.

\section{References}

1. World Health Organization. Coronavirus disease 2019 (COVID-19): situation report, 82. 2020.

2. COVID-19 India. Tracker, 2020. [Online]. Available from: https://www.covid19india.org/ . [accessed on 02 Feb 2021].

3. COVID-19 Statewise Status. Available from: https://www.mygov.in/covid-19 . [accessed on 02 Feb 2021].

4. Marston C, Renedo A, Miles S. Community participation is crucial in a pandemic. Lancet. 2020;395(10238):1676-1678. doi: 10.1016/S0140-6736(20)31054-0. Epub 2020 May 4. PMID: 32380042; PMCID: PMC7198202.[PubMed].

5. The COVID-19 Crisis Is Moving to India's Rural Areas. Available from: https://science.thewire.in/health/covid-19india-urban-rural// [accessed on 02 Feb 2021].

6. World Health Organization. Emerging respiratory viruses, including COVID-19: methods for detection, prevention, response and control. Available from: https://openwho.org/courses/introduction-to-ncov [accessed on 02 Feb 2021].

7. Ministry of Health and Family Welfare. Training Resources for COVID 19 Management. Available from: https://www.mohfw.gov.in/pdf/TrainingresourcesforCOVI D1930MARCH.pdf . [accessed on 02 Feb 2021].

8. . Tamang N, Rai P, Dhungana S, Sherchan B, Shah B, Pyakurel P, Rai S. COVID-19: a National Survey on perceived level of knowledge, attitude and practice among frontline healthcare Workers in Nepal. BMC Public Health. 2020 Dec 14;20(1):1905. doi: 10.1186/s12889-020-10025-8. PMID: 33317486; PMCID: PMC7734608.[PubMed]

9. Yousaf MA, Noreen M, Saleem T, Yousaf I. A Cross-Sectional Survey of Knowledge, Attitude, and Practices (KAP) Toward Pandemic COVID-19 Among the General Population of Jammu and Kashmir, India. Soc Work Public Health. 2020;35(7):569-578.

doi: 10.1080/19371918.2020.1806983. PMID: 32970548. [PubMed]

10. Olum R, Chekwech G, Wekha G, Nassozi DR, Bongomin F. Coronavirus Disease-2019: Knowledge, Attitude, and Practices of Health Care Workers at Makerere University Teaching Hospitals, Uganda. Front Public Health. 2020;8:181. doi: 10.3389/fpubh.2020.00181. PMID: 32426320; PMCID: PMC7204940.[PubMed] 


\section{Tables}

TABLE 1 DEMOGRAPHIC PROFILE AND COMPARISON OF KNOWLEDGE, ATTITUDE AND PRACTICE SCORES AMONG DIFFERENT DEMOGRAPHIC VARIABLES BY UNIVARIATE ANALYSIS

\begin{tabular}{|c|c|c|c|c|c|c|c|c|c|c|c|}
\hline \multirow[t]{2}{*}{ Factors } & \multirow[t]{2}{*}{ Category } & \multirow[t]{2}{*}{ Total } & \multicolumn{2}{|c|}{ Knowledge } & \multirow[t]{2}{*}{ P value } & \multicolumn{2}{|c|}{ Attitude } & \multirow{2}{*}{$\begin{array}{c}P \\
\text { value }\end{array}$} & \multicolumn{2}{|c|}{ Practice } & \multirow{2}{*}{$\begin{array}{c}P \\
\text { value }\end{array}$} \\
\hline & & & Mean & SD & & Mean & SD & & Mean & SD & \\
\hline \multirow[t]{2}{*}{ Age } & $>35$ years & 237 & 21.16 & 3.38 & \multirow[b]{2}{*}{$0.005^{*}$} & 29.60 & 2.98 & \multirow[b]{2}{*}{$0.003 *$} & 8.16 & 1.23 & \multirow[t]{2}{*}{0.443} \\
\hline & $\leq 35$ years & 263 & 21.90 & 2.52 & & 30.35 & 2.74 & & 8.24 & 1.27 & \\
\hline \multirow[t]{2}{*}{ Gender } & Female & 304 & 21.40 & 3.18 & \multirow[t]{2}{*}{0.145} & 29.94 & 2.81 & \multirow[b]{2}{*}{0.616} & 8.19 & 1.31 & \multirow[b]{2}{*}{0.89} \\
\hline & Male & 196 & 21.80 & 2.61 & & 30.08 & 3.01 & & 8.20 & 1.21 & \\
\hline \multirow[t]{2}{*}{ Occupation } & Unemployed & 205 & 21.15 & 3.39 & \multirow[b]{2}{*}{$0.011^{*}$} & 29.92 & 2.85 & \multirow[b]{2}{*}{0.632} & 8.35 & 1.26 & \multirow[b]{2}{*}{$0.001^{*}$} \\
\hline & Employed & 295 & 21.84 & 2.62 & & 30.05 & 2.91 & & 7.98 & 1.20 & \\
\hline \multirow[t]{2}{*}{ Education } & $\begin{array}{l}\text { Upto10 } 10^{\text {th }} \\
\text { standard }\end{array}$ & 186 & 20.56 & 3.63 & \multirow[b]{2}{*}{$<0.001^{*}$} & 29.42 & 2.79 & \multirow[t]{2}{*}{$0.001 *$} & 8.17 & 1.35 & \multirow[t]{2}{*}{0.67} \\
\hline & $\begin{array}{l}\text { More than } \\
10^{\text {th }} \text { standard }\end{array}$ & 314 & 22.14 & 2.33 & & 30.33 & 2.88 & & 8.22 & 1.19 & \\
\hline \multirow[t]{2}{*}{ SES } & Class IV,V & 92 & 20.71 & 3.74 & & 29.80 & 3.01 & \multirow[b]{2}{*}{0.480} & 7.95 & 1.31 & \multirow[t]{2}{*}{0.034} \\
\hline & Class I,II,III & 408 & 21.75 & 2.74 & $0.002^{*}$ & 30.04 & 2.85 & & 8.25 & 1.23 & \\
\hline \multirow{2}{*}{$\begin{array}{l}\text { Children < } \\
12 \text { years in } \\
\text { the home }\end{array}$} & Yes & 197 & 21.80 & 2.63 & \multirow[b]{2}{*}{0.142} & 30.04 & 2.85 & \multirow[b]{2}{*}{0.675} & 8.32 & 1.26 & \multirow[t]{2}{*}{$0.008^{*}$} \\
\hline & No & 303 & 21.40 & 3.18 & & 29.93 & 2.92 & & 8.01 & 1.21 & \\
\hline
\end{tabular}

TABLE 2 MULTIVARIATE LINEAR REGRESSION OF ASSOCIATION BETWEEN DEMOGRAPHIC CHARACTERISTICS WITH KNOWLEDGE, ATTITUDE AND PRACTICE SCORES OF COVID-19

\begin{tabular}{|c|c|c|c|c|c|c|c|}
\hline & \multirow[t]{2}{*}{ Factor } & \multicolumn{2}{|l|}{ Knowledge } & \multicolumn{2}{|l|}{ Attitude } & \multicolumn{2}{|l|}{ Practice } \\
\hline & & $\begin{array}{l}\text { Unstandardized } \\
\text { coefficient } \\
\text { B }(95 \% \mathrm{Cl})\end{array}$ & $P$ value & $\begin{array}{l}\text { Unstandardize } \\
\text { d } \\
\text { coefficient } \\
B(95 \% \mathrm{Cl})\end{array}$ & $\begin{array}{l}P \\
\text { value }\end{array}$ & $\begin{array}{l}\text { Unstandardized } \\
\text { coefficient } \\
B(95 \% \mathrm{Cl})\end{array}$ & $P$ value \\
\hline Age & $\begin{array}{l}>35 \text { years } \\
\leq 35 \text { years }\end{array}$ & $\begin{array}{c}0.33 \\
(-0.22 \text { to } 0.84)\end{array}$ & .230 & $\begin{array}{c}0.69 \\
(0.12 \text { to } 1.24)\end{array}$ & $.016^{*}$ & $\begin{array}{c}0.07 \\
(-0.16 \text { to } 0.31)\end{array}$ & .571 \\
\hline Gender & $\begin{array}{l}\text { Female } \\
\text { Male }\end{array}$ & $\begin{array}{c}0.03 \\
(-0.61 \text { to }-0.64)\end{array}$ & .928 & $\begin{array}{c}0.01 \\
(-0.61 \text { to } 0.57)\end{array}$ & .954 & $\begin{array}{c}0.34 \\
(-0.05 \text { to } 0.61)\end{array}$ & 0.09 \\
\hline Occupation & $\begin{array}{l}\text { Unemployed } \\
\text { Employed }\end{array}$ & $\begin{array}{c}0.73 \\
(0.12 \text { to } 1.28)\end{array}$ & $.016^{*}$ & $\begin{array}{c}0.21 \\
(-0.34 \text { to } \\
0 . .76)\end{array}$ & .469 & $\begin{array}{c}0.53 \\
(0.27 \text { to } 0.78)\end{array}$ & $.002 *$ \\
\hline Education & $\begin{array}{l}\text { More than } 10^{\text {th }} \\
\text { standard } \\
\text { Upto } 10^{\text {th }} \\
\text { standard }\end{array}$ & $\begin{array}{c}1.35 \\
(0.73 \text { to } 1.95)\end{array}$ & $.002 *$ & $\begin{array}{c}0.75 \\
(0.18 \text { to } 1.34)\end{array}$ & $.012 *$ & $\begin{array}{c}-0.01 \\
(-0.24 \text { to } 0.25)\end{array}$ & .936 \\
\hline SES & $\begin{array}{l}\text { Class IV,V Class } \\
\mathrm{I}, \mathrm{II}, \mathrm{III}\end{array}$ & $\begin{array}{c}0.45 \\
(-0.29 \text { to } 1.22)\end{array}$ & .273 & $\begin{array}{c}0.14 \\
(-0.85 \text { to } 0.51)\end{array}$ & .675 & $\begin{array}{c}0.25 \\
(-0.02 \text { to } 0.56)\end{array}$ & .100 \\
\hline $\begin{array}{l}\text { Children }<12 \\
\text { years in the } \\
\text { home }\end{array}$ & $\begin{array}{l}\text { Yes } \\
\text { No }\end{array}$ & $\begin{array}{c}0.25 \\
(-0.19 \text { to }-0.74)\end{array}$ & .299 & $\begin{array}{c}0.38 \\
(-0.84 \text { to } 0.17)\end{array}$ & .160 & $\begin{array}{c}0.31 \\
(0.07 \text { to } 0.57)\end{array}$ & $.010 *$ \\
\hline
\end{tabular}

